Biografistyka Pedagogiczna

Rok 5 (2020) nr 1

ISSN 2543-6112; e-ISSN 2543-7399

DOI: $10.36578 /$ BP.2020.05.17

Marta M. Kacprzak*

\title{
Wymiar wychowawczo-edukacyjny biografii pisarza staropolskiego. Wokół jubileuszu Mikołaja Reja i prac oświatowych w Królestwie Polskim na początku XX w. ${ }^{1}$ \\ The Educational Dimension of the Biography of the Old Polish Writer: The Jubilee of Mikołaj Rej and Educational Works in the Kingdom of Poland in the Early 2oth century
}

\begin{abstract}
The anniversary of Mikołaj Rej's birth in 1905 was one of the jubilees in the 19th and early 2oth century, during which the patriotic history of the former Polish-Lithuanian Commonwealth was remembered, with the old Polish writers presented as role models and their works having educational impact. Numerous historical and literary, editorial, popularisation and educational works were published at that time. The biography of the old Polish writer Rej was used in them for pedagogical purposes. The article analyses three examples of publications for children and youth and the people. It shows how their authors overcame the ideological and pedagogical difficulties (connected with the stereotype of Rej the ignoramus and the writer's involvement in the religious disputes of the 16th century) to depict Rej as a role model and patron of contemporary educational work.
\end{abstract}

Keywords: biography of the writer, history of education, children's and youth literature, reception of Old Polish culture, Mikołaj Rej (Rey).

* Marta M. Kacprzak (ORCID: 00oo-ooo2-0491-7970) - dr, kustosz w Bibliotece Uniwersytetu Warszawskiego, kontakt: m.m.kacprzak@uw.edu.pl.

1 Praca naukowa finansowana w ramach programu Ministra Nauki i Szkolnictwa Wyższego pod nazwą „Szlakami Polski Niepodległej” w latach 2018-2023, nr projektu O1SPN 170020 18, kwota finansowania 751222 zł. 


\section{Okolicznościowo i wychowawczo}

Tikołaj Rej urodził się w 1505 r. i czterechsetna rocznica tego faktu w 1905 r. 1 miała stać się kolejnym z szeregu jubileuszy, które świętowano w XIX i na progu XX w., aby przypominać w duchu patriotycznym dzieje dawnej Rzeczypospolitej - po 400-leciu śmierci Jana Długosza w 1880 r. i 30o-leciu śmierci Jana Kochanowskiego w 1884 r., a przed 30o-leciem śmierci Piotra Skargi w 1912 roku ${ }^{2}$. Do rocznicy Rejowej przygotowywały Polaków liczne publikacje historycznoliterackie, edytorskie i popularyzatorskie przynajmniej od $1900 \mathrm{r}$., a obfity plon obchodzonego we wszystkich trzech zaborach jubileuszu zanotował „Pamiętnik Literacki” za 1905 r., wydawany we Lwowie przez Towarzystwo Literackie im. Adama Mickiewicza. Zamieszczono w nim m.in. zestawioną przez Wiktora Hahna dziesięciostronicową Bibliografię o Mikołaju Reju za rok 1905, która ukazuje skalę obchodów - obejmuje edycje dzieł Reja i ich recenzje, liczne Studia, rozprawy, artykuły okolicznościowe o życiu i pismach Reja i ich recenzje, Utwory poetyczne poświęcone Rejowi lub osnute na tle jego życia (dzieła literackie z recenzjami), księgi zbiorowe i numery czasopism z wyszczególnieniem zawartości, publikacje i dokumenty życia społecznego związane z rocznicą i ich recenzje, a także Obchody ku czci Reja (zestawione alfabetycznie według nazw). Ostatni dział to szczególnie ciekawy spis wydarzeń kulturalno-oświatowych w Białej, Cieszynie, Krakowie, Lwowie, Przemyślu, Rapperswilu, Skolu, Stanisławowie, Tarnopolu i Warszawie, obejmujący odczyty i wykłady popularyzatorskie dla różnych audytoriów, wieczornice i uroczyste poranki, nabożeństwa, odsłonięcie tablicy, przedstawienia teatralne i relacje prasowe o tych imprezach. W spisie wspomina się też o przygotowaniach do Zjazdu Historycznoliterackiego im. Mikołaja Reja ${ }^{3}$, który Akademia Umiejętności w Krakowie zorganizowała ostatecznie w lipcu 1906 r. Ta obfitość związanych z rocznicą wydarzeń społeczno-kulturalnych oraz publikacji popularyzatorskich i naukowych przyciągała uwagę odbiorców w różnym stopniu zainteresowanych literaturą, historią i kulturą dawnej Polski, a także współczesną oświatą i edukacją. Wzorem jubileuszu Kochanowskiego, w związku z którym ogłoszono w trzech zaborach

2 U. Kowalczuk, 1884 - jubileuszowa „renowacja” Kochanowskiego, w: Upominki od narodu. Jubileusze, rocznice, obchody pisarzy, red. T. Budrewicz i in., Żarnowiec 2000.

3 W. Hahn, Bibliografia o Mikołaju Reju za rok 1905, „Pamiętnik Literacki”, 4 (1905) s. 577. 
liczne popularne biografie twórcy o wyraźnych celach oświatowych i wychowawczo-edukacyjnych ${ }^{4}$, także okolicznościowe zainteresowanie postacią Reja chciano wykorzystać w ten sposób - przedstawiając biografię staropolskiego pisarza w celu oddziaływania pedagogiczno-oświatowego.

Tymczasem budowanie narracji, w których Rej mógłby stać się wzorem do naśladowania czy nośnikiem jednoznacznie pozytywnych wartości proponowanych dzieciom, młodzieży i - traktowanemu jako podobny typ odbiorcy ludowi ${ }^{5}$, było niełatwe. Nieoczywistość takiego potraktowania pisarza wynikała z jego obrazu, który niosły wieki minione. Rej, bardzo ceniony przez swych współczesnych, od początku miał i przeciwników gorliwie krzątających się wokół jego złej sławy, zwykle z powodu jego zaangażowania w spory religijne ${ }^{6}$. Jednak i pozytywne przekazy o nim z XVI w. nie zawsze rozumiano w następnych epokach właściwie. Dwa staropolskie świadectwa o Reju, które Michał Hieronim Juszyński przypomniał w XIX w. w Dykcjonarzu poetów polskich (Kraków 1820),

4 Jan Kochanowski z Czarnolasu. Opowiadanie, Warszawa 1883; K. Promyk [K. Prószyński], O Janie Kochanowskim z Czarnolasu, jego pieśniach i pamiątkach po nim, w 300 lat po śmierci tego pieśniarza, Warszawa 1884; Podolanka [M. Sandoz], Obrazki z życia Jana Kochanowskiego, Kraków 1884; B. Sokalski, O Janie Kochanowskim, jego życiu i dziełach, Złoczów 1884; Z. S. [Z. Ścisłowska], Jan Kochanowski, dziedzic Czarnolasu, obrazek historyczny $z$ XVI wieku, popularne opowiadanie, Kraków 1884; L. Tatomir, Jan Kochanowski, Lwów 1884. Por. A. Niewolak-Krzywda, W kręgu rzeczy czarnoleskiej, Rzeszów 1987, s. 87-90; U. Kowalczuk, 1884 - jubileuszowa „renowacja”, s. 113, M. M. Kacprzak, Jan z Czarnolasu jako bohater literacki w poezji polskiej XIX w. Z dziejów recepcji spuścizny Kochanowskiego i kultury staropolskiej w wieku XIX, w: Wiąanie sobótkowe. Studia o Kochanowskim, red. E. Lasocińska, W. Pawlak, Warszawa 2015.

5 R. Górski, Literatura dla ludu, w: Słownik literatury polskiej XIX wieku, red. J. Bachórz, A. Kowalczykowa, Wrocław 1991.

6 E. Ostrowska, Rej w ocenie Kochanowskiego, w: tejże, Z dziejów języka polskiego i jego piękna. Studia i szkice, Kraków 1978; A. Chrobot, Mikołaj Rej w twórczości Andrzeja Trzecieskiego, w: Mikołaj Rej z Nagłowic. W pięćsetna rocznicę urodzin, red. W. Kowalski, Kielce 2005; S. Nieznanowski, Recepcja Reja w literaturze staropolskiej, w: Mikołaj Rej. W czterechsetlecie śmierci, red. T. Bieńkowski, J. Pelc, K. Pisarkowa, Wrocław 1971; W. Walecki, Święty Rej. Dwa przypomnienia: o człowieku i o pisarzu, w: Mikołaj Rej z Nagłowic. Sylwetka - twórczość - epoka, red. M. Garbaczowa, Kielce 1997; M. Kuran, Mikołaj Rej w opinii polskiej kontrreformacji (na przykładzie „Postylli katolicznej" Jakuba Wujka), w: Mikołaj Rej - w pięćsetlecie urodzin, red. J. Okoń i in., Eódź 2005; B. Mazurkowa, Glosa do recepcji „Zwierciadła” Mikołaja Reja (XVI-XVIII w.), w: Mikołaj Rej-w pięćsetlecie urodzin. 
kształtują postrzeganie pisarza jako ambiwalentne; obydwa maja zresztą uwarunkowania w sporach wyznaniowych XVI w. Przekaz pierwszy to kilkustronicowa biografia Żywot i sprawy poćciwego ślachcica polskiego Mikołaja Reja $z$ Nagłowic, z woli Reja dołączona do jego ostatniego dzieła Źwierciadło (Kraków 1567/1568). Została podpisana przez Andrzeja Trzecieskiego młodszego, współbrata pisarza w Zborze reformowanym, ale o jej autorstwo czy współautorstwo podejrzewa się czasem samego Reja ${ }^{7}$. Przez cały XIX i dużą część XX w. stanowiła ona zasadnicze źródło informacji o życiu pisarza. Jego postać przedstawiono tu niewątpliwie życzliwie, a nawet ze skłonnością do idealizacji, specyficznego ujęcia panegirycznego i parenetycznego. Specyficznego, bo ta biografia (autobiografia?) zawiera szczególną kreację literacką. Podkreśla nieuctwo i przypadkowość wykształcenia Reja. Służyło to w istocie przedstawieniu pisarza jako Bożego prostaczka, którego do pracy literackiej i innych działań pobudziła Ewangelia, a nie jakakolwiek siła ludzka, który skromnie wyrzeka się wszelkiej zasługi, a wszystko przypisuje Bożej Mądrości, nie ludzkiemu rozumowi i wykształceniu. Nie ma to nic wspólnego z propagowaniem nieuctwa i pogardy dla nauki. Nie odzwierciedla też w pełni rzeczywistej roli edukacji w życiu Reja, który wprawdzie nie zdobył regularnego wykształcenia, ale którego pisma (zwłaszcza te o tematyce teologicznej czy filozoficznej, jak Apocalypsis, Postylla, Wizerunk własny żywota człowieka poćciwego) dowodzą, że mamy do czynienia z jednym z najbardziej oczytanych pisarzy staropolskich, dzięki samokształceniu zaznajomionym z literaturą i kulturą biblijną, starożytną i współczesną, świadomym problemów ideowych renesansu i ich realizacji literackich. Jednak dla pedagogów i działaczy oświatowych przełomu XIX/XX w. to deklarowane w XVI-wiecznej biografii nieuctwo czy niedouczenie stanowiło konkretny problem.

Problem tym większy, że biografia sygnowana przez Trzecieskiego spotykała się z drugim XVI-wiecznym przekazem o Reju - wspomnieniem Józefa Wereszczyńskiego, z utworu o znamiennym tytule Gościniec pewny niepomiernym moczygębom a obmierzłym wydmikuflom świata tego (Kraków 1585), zawierającym iście gargantuiczny obraz pisarza, którego nieumiarkowanie w jedzeniu i piciu szczególnie raziło w zestawieniu z naukami moralnymi z jego dzieł.

7 T. Witczak, Spór o „Żywot i sprawy poćciwego szlachcica polskiego Mikołaja Reja $z$ Nagłowic”, „Pamiętnik Literacki”, 65 (1974) nr 2, s. 3-44; J. T. Maciuszko, Mikołaj Rej. Zapomniany teolog ewangelicki XVI w., Warszawa 2002. 
Ksiądz Wereszczyński, opat benedyktyński i polemista, z pewnością pisał ten tekst przeciw oddziaływaniu Reja jako szermierza reformacji, autora ewangelickiej Postylli. Na wieki dołożył do stereotypu Reja-nieuka stereotyp Reja-żarłoka, opilca i, co gorsza, fałszywego moralisty. A nie był w tych opiniach osamotniony - w XIX w. Juszyński mógł przypomnieć także inne wynotowane z dawnych rękopisów negatywne wypowiedzi o Reju ${ }^{8}$. Te przekazy, mimo prowadzonych w XIX w. rzeczowych badań nad życiem i twórczością Reja, ukształtowały na progu nowego stulecia obraz pisarza trudny do wykorzystania w dydaktyce. Umieściły go także na tle walk wyznaniowych XVI w., co również uznawano za niepożądane w budującej lekturze.

W polityczno-społecznych realiach zaborów, gdy odwołaniom do przeszłości Rzeczypospolitej przypisywano ważną rolę w utwierdzaniu tożsamości i wspólnoty narodowej, ukazywanie konfliktów etnicznych czy religijnych z historii ojczyzny nie było dobrze widziane w pismach dla młodego i prostego odbiorcy. W literaturze pouczającej XIX w. chętnie łączono patriotyzm z katolicyzmem w prosty sposób i tworzono szablonowych bohaterów, którzy prezentowali katalog cnót dobrego Polaka, cechującego się m.in. miłością ojczyzny i bogobojnością w wierze katolickiej. Dzieła propagujące patriotyzm i katolicyzm wysoko oceniano w recenzjach ${ }^{9}$. Protestantyzm często postrzegano jako zjawisko niepolskie, niezwiązane z umiłowaniem ojczyzny, a więc niewłaściwe z wychowawczego punktu widzenia. Większe skomplikowanie ideowe, które musiało się wiązać z przypominaniem konfliktów religijnych i etnicznych dawnej Rzeczypospolitej, budziło obawy co do skuteczności budującego oddziaływania lektury. Na przykład Stefania Sempołowska w 1901 r. w artykule Zasady moralne a literatura dla dzieci zwracała uwagę na niepożądane idee powieści historycznych, które mogą krzewić „nienawiści narodowe i wyznaniowe” ${ }^{\prime 10}$. Tymczasem, przedstawiając biografię Reja na przełomie XIX/XX w., nie sposób było przejść milcząco obok jego życzliwego protestantyzmowi udziału w kulturze religijnej epoki i jej ostrych konfrontacjach. Przez cały XIX w. popularyzatorzy twórczości Reja widzieli w jego przychylności dla protestantyzmu swoistą rysę

8 M. H. Juszyński, Dykcjonarz poetów polskich, t. 2, Kraków 1820, s. 106-119.

9 G. Skotnicka, Pozytywistyczne powieści z dziejów narodu dla dzieci i młodzieży, Gdańsk 1974, s. 34-35, 197.

10 S. Sempołowska, Zasady moralne a literatura dla dzieci, „Poradnik dla Czytających Książki", 23 (1901) s. 8-10; G. Skotnicka, Pozytywistyczne powieści, s. 12-13. 
na patriotyzmie. Już dla anonimowego autora przedmowy do edycji Żywota człowieka poczciwego z 1828 r. protestantyzm stanowił ograniczenie wymowy moralnej dzieła ${ }^{11}$, a w życiorysie ze zbioru $Z$ rodzinnej zagrody z 1877 r. Kazimierz Władysław Wójcicki odnosił się do wyboru konfesyjnego pisarza z protekcjonalną wyrozumiałością ${ }^{12}$. Kiedy zaś już udawało się obronić Reja przed obrazem niemoralnego protestanta (o źródłach w tekście Wereszczyńskiego), pozostawał jeszcze trudny obraz z biografii Trzecieskiego: Rej-nieuk.

Jak więc można było pisać budująco o życiu i twórczości Reja, gdy zbliżał się jubileusz 1905 r., skądinąd stanowiący tak dobrą okazję dla silnego oddziaływania publikacji wychowawczo-oświatowych? Przyjrzyjmy się trzem tekstom dla młodych i prostych odbiorców, wydanym w Warszawie w związku z rocznicą Rejową - przykładom zastosowania kontrowersyjnej biografii pisarza staropolskiego do celów wychowawczych na progu wieku $\mathrm{xx}^{13}$.

\section{Mikołaj Rej z Nagłowic Bronisława Brzozowskiego}

W 1900 r. w Warszawie wyszła książeczka Mikołaj Rej z Nagłowic autorstwa Bronisława Brzozowskiego (Warszawa 1900). Ten niezbyt znany warszawski nakładca prowadził działalność wydawniczą od 1889 r. w Księgarni Tanich

11 Przedmowa do nowego wydania Reja, w: M. Rej, Żywot człowieka poczciwego, Warszawa 1828 , t. 6 , s. VII.

12 K. W. Wójcicki, Mikołaj Rej z Nagłowic, w: tegoż, Z rodzinnej zagrody. Życiorysy, Warszawa 1877, s. 18.

13 Niniejsze opracowanie odnosi się do warunków społeczno-politycznych Królestwa Polskiego i nie zawiera analizy podobnych publikacji z zaboru pruskiego i austriackiego (J. Magiera, Mikołaj Rej. Ojciec piśmiennictwa polskiego. Opowiadanie z dziejów literatury polskiej. W czterechsetletną rocznicę urodzin Reja 1505-1905, Kraków 1905; C. Pieniążek, O życiu i dziełach Mikołaja Reja z Nagłowic, Lwów 1905; W. Bruchnalski, Mikołaj Rej 1505-1905. Odczyt wygłoszony w sali Teatru Lwowskiego podczas Uroczystości jubileuszowej 17 grudnia 1905, Lwów 1906; J. Kallenbach, Mikołaj Rey. Szkic jubileuszowy, Kraków 1906). Do analizy nie wybraliśmy także publikacji z terenu Królestwa, których charakter należy określić jako przede wszystkim naukowy (B. Chlebowski, Mikołaj Rej jako pisarz. Odbitka z książki zbiorowej pt. „Z wieku Reja” ku uczczeniu czterechsetnej rocznicy urodzin poety, Warszawa 1905) lub literacki (A. Nowaczyński, Wizerunek Mikołaja Reja z Nagłowicz, Warszawa 1905) oraz popularyzatorsko-wychowawczych, ale pomijających zagadnienia biograficzne (Złote myśli Mikołaja Reja, wybrał i ułożył R. Kwiatkowski, Warszawa 1906). 
Wydawnictw Mariana A. Wizbeka. Wcześniej wydał m.in. w 1898 r., z okazji jubileuszu 100-lecia urodzin Adama Mickiewicza, inkrustowaną fragmentami jego wierszy rozprawkę O wielkim pieśniarzu Adamie Mickiewiczu oraz Zbiorek poezji Adama Mickiewicza dla ludu i młodzieży z objaśnieniami i życiorysem antologię, poprzedzoną kilkustronicową biografią Wieszcza ${ }^{14}$. Publikując rozprawkę o Reju, poszedł tym samym jubileuszowym tropem, chcąc uczcić także bardziej zamierzchłego polskiego pisarza i przedstawić go ludowi i młodzieży (choć tym razem nie sformułował adresu czytelniczego wprost jak w przypadku Mickiewicza). Informacja o roku urodzenia Reja została tu wprowadzona określeniem „prawie 400 lat temu” (s. 4) ${ }^{15}$, co wyraźnie plasuje publikację w kontekście nadchodzącego jubileuszu. Krótka (16 ss.) i mała (18 cm) książeczka, ozdobiona na stronie tytułowej współczesnym, choć opartym na rycinach z XVI w. portretem, oprócz życiorysu i charakterystyki twórczości pisarza zawiera 6 jego krótkich utworów.

Pierwsze zdanie rozprawki tłumaczy potrzebę zainteresowania dawnym i raczej nieznanym bliżej odbiorcy pisarzem - przedstawiono go patetycznie jako patriarchę piśmiennictwa polskiego, który jako „jeden z najpierwszych zaczął pisać książki w języku polskim" (s. 3), gdy wcześniej i później w polskim piśmiennictwie dominowała łacina. Dziś oczywiście nie zaskakuje ta teza, że znaczenie dziejowe Reja jest związane z emancypacją polszczyzny jako języka literatury polskiej, jednak w książeczce popularyzatorsko-oświatowej w Królestwie Polskim w 1900 r. ma to wymiar szczególny: zwraca uwagę na potrzebę walki o rolę polszczyzny w kulturze i edukacji. Aspekt ten uwydatnia się tym bardziej, że autor, zanim przejdzie do systematycznego przedstawienia życiorysu pisarza, odnosi się do kwestii jego wykształcenia i poziomu wykształcenia ówczesnego społeczeństwa. To oczywiście przywołanie tradycyjnego obrazu Reja ze staropolskiej biografii Trzecieskiego, jednak nie sposób nie interpretować go także jako odniesienia do aktualnych na przełomie XIX/XX w. kwestii oświatowych i do adresata książki. Rej został tu przedstawiony jako człowiek

14 M. M. Kacprzak, XIX-wieczne edycje dzieł Adama Mickiewicza dla dzieci i młodzieży, w: Aspekty działalności wydawniczej w XIX i początkach XX wieku, red. I. Michalska, G. Michalski, Łódź 2016.

15 B. Brzozowski, Mikołaj Rej z Nagłowic, Warszawa 190o. Cytaty z publikacji lokalizujemy, podając numery stron w nawiasach po przytoczeniach. 
nieuczony, który jednak - będąc zdolny z natury, cechując się bystrym umysłem, zdrowym rozsądkiem i jasnym sądem - zdobył dużą wiedzę, podróżując po kraju, spotykając się z ludźmi, obserwując wydarzenia. W efekcie tego naturalnego samokształcenia, „gdy się zabrał do pisania, mógł ludziom dużo naopowiadać ciekawego" (s. 3). To jego osiągnięcie podkreślono przez ukazanie na tle stanu współczesnej mu oświaty, negatywnie porównanej z współczesnością odbiorcy z 1900 r:: „żył w czasach, gdy nauka i piśmiennictwo w Polsce nie były tak rozwinięte jak dzisiaj" (s. 3). W stwierdzeniu tym niewątpliwie jest niedocenienie kultury renesansowej i nieuzasadniona deprecjacja jakości wykształcenia humanistycznego; teza ma rację bytu wyłącznie w odniesieniu do kwestii powszechności wykształcenia niższych warstw społecznych. Jednak dzięki temu stwierdzeniu odbiorca książeczki może zobaczyć jej bohatera jako przechodzącego drogę: od braku wykształcenia, przez samokształcenie, do uczenia mniej oświeconych - i może tej drogi pozazdrościć, tudzież zechcieć nią podążyć.

Niemal wyłącznie do tematu wykształcenia i jego roli w życiu młodego Reja odnoszą się także fragmenty przytoczone z biografii Trzycieskiego. Dowiadujemy się z nich o roli rodziny - o ojcu pisarza jako pobożnym, przyzwoitym, stroniącym od godności publicznych człowieku, nieco ograniczonym, ale dbałym o jedynaka, a dbałość tę wyrażającym przez wychowywanie domowe i zapewnienie podstawowego wykształcenia w pobliskiej szkole parafialnej. Kolejny fragment XVI-wiecznej biografii (przytaczanej zresztą bezkrytycznie, bez brania pod uwagę kreacji literackiej) mówi konkretnie o edukacji Reja, który, przedkładając nad naukę spędzanie czasu z przyjaciółmi, nic nie wyniósł z tej pierwszej szkoły, podobnie jak z kolejnej we Lwowie, a także z Akademii Krakowskiej (notabene w przypisie do opisu pobytu w tzw. bursie Jeruzalem pojawia się tu ciekawe, choć niezbyt precyzyjne objaśnienie z historii szkolnictwa: „Był to zakład przy wyższej szkole w Krakowie, uniwersytetem zwany. W bursie Jerozolimskiej, młodzież przybywająca do szkoły, na naukę, ze swoimi nauczycielami zamieszkiwała", s. 5). I znów pojawia się przed naszymi oczyma postać kochającego ojca, nieświadomego potrzeb wykształcenia, sprowadzającego młodzieńca do domu, gdzie otoczony powszechnym zachwytem marnuje życie na zabawy. Kolejny fragment z biografii Trzecieskiego mówi o dobroczynnym wpływie, jaki na młodego pisarza miał pobyt na dworze Andrzeja Tęczyńskiego, gdzie w otoczeniu mądrych ludzi Rej gorliwie nadrobił braki w wykształceniu literackim, uczył się pisania listów i podjął amatorską naukę zaniedbanej wcześniej łaciny. W tym kontekście 
słowa o stałej skłonności do towarzystwa, muzyki i polowania oraz o ciekawości świata, przeszkadzającej w nauce i pracy, brzmią już mniej krytycznie, zwłaszcza że towarzyszy im informacja o wrodzonym talencie literackim.

Można by rzec, że tu tak naprawdę kończy się biografia Reja pióra Brzozowskiego. Omówiwszy młodość i wykształcenie, autor przestaje korzystać z relacji Trzecieskiego i niczym jej nie uzupełnia, przechodzi zaś do prezentacji charakteru i twórczości pisarza. Wspomina jeszcze o osiedleniu się w majątku, ożenku i rolnictwie oraz sprawach publicznych jako głównych zajęciach Reja, ale skupia się na realizowanej z zapałem i poświęceniem jego pasji - twórczości literackiej. Wraca wspomniana na wstępie kwestia wyboru, wbrew ówczesnej praktyce, języka polskiego w pisarstwie. Zacytowanie po raz pierwszy samego Reja - słynnego dwuwiersza ze Zwierzyńca o Polakach, którzy mają własny, a nie gęsi język - eksponuje zagadnienie języka narodowego, które, jak wiemy z początku rozprawki, jest racją bytu zainteresowania Rejem i czczenia jego rocznicy.

Brzozowski podkreśla, że bogata twórczość Reja to w znacznej mierze skutek jego cech, do których należały: „Ruchliwość, olbrzymi sił zasób, tęgie zdrowie, bystry i doświadczony umysł, wielka spostrzegawczość" (s. 7). Autor wymienia najważniejsze utwory (podając tytuły w zmodernizowanej i skróconej formie): Żywot Józefa, Wizerunek, Zwierzyniec, Zwierciadło z jego szczególną częścią - Żywotem człowieka poczciwego, Krótką rozprawę, blok określony jako „Dzieła religijne: Przekład psalmów Dawida, Wykład zasad ewangelii i Objawienie Świętego Jana" (s. 8) - czyli Psatterz, Postyllę i Apocalypsis, wreszcie Figliki. Brzozowski zatrzymuje dłużej uwagę odbiorcy na Żywocie człowieka poczciwego, określonym jako „Spomiędzy wszystkich książek Reja najgłówniejsza co do treści, znaczenia i rozmiarów" (s. 8), dzieło pisarza już dojrzałego i ustatkowanego. Nie dziwi ta waloryzacja, zgodna z tradycją staropolską, a w XIX w. utwierdzona przez prace historycznoliterackie oraz liczne edycje tej usamodzielnionej części Zwierciadła ${ }^{16}$, ciekawi natomiast dość szczegółowe przedstawienie treści dzieła. Autor ukazuje je jako złożony z trzech części (młodość, dojrzałość, starość) opis życia człowieka, rozpoczęty dyskursem o stworzeniu świata i człowieka oraz o grzechu pierworodnym, a rozwijający się w refleksję o naturze

16 M. M. Kacprzak, Edycje literatury staropolskiej w życiu Polaków XIX w. na przykładzie wydań „Zwierciadła” Mikołaja Reja, w: Na co dzień i od święta. Książka w życiu Polaków w XIX-XXI wieku, red. A. Chamera-Nowak, D. Jarosz, Warszawa 2015. 
ludzkiej i rządzących nią prawach. Brzozowskiemu zależy na podkreśleniu uniwersalności tej antropologicznej i etycznej refleksji Reja i dlatego poczuwa się do usprawiedliwienia wymowy stanowej (szlacheckiej) utworu - tłumaczy ją biografią pisarza. Rej znał wyłącznie polskie stosunki szlacheckie, więc chcąc ukazać żywot ludzki, odtworzył okoliczności życia szlachty. Przywołując sąd Adama Mickiewicza o Reju ze słynnych wykładów o literaturze słowiańskiej w Collège de France ${ }^{17}$, Brzozowski doprecyzował jeszcze, że znaczenie Żywota człowieka poczciwego wynika właśnie z zobrazowania wiejskiego życia domowego w dawnej Polsce. Pisze to, by odbiorca książeczki nie czuł się wyłączony z kręgu odbiorców XVI-wiecznego dzieła. Notabene ekskluzywny aspekt konfesyjny - protestancki - twórczości Reja został tu całkowicie pominięty.

Brzozowski twierdzi, że sposób, w jaki Rej ukazuje Polskę, wynika z jego miłości do ojczyzny, nie jest to jednak miłość bezkrytyczna, bo nie zamyka oczu na wady Polaków i gromi je (zbytki w strojach, pojazdach, potrawach, biesiady przeradzające się w pijatyki i kłótnie), pragnąc dla ojczyzny spokoju i dobrobytu. W krótkiej charakterystyce pozostałych dzieł pisarza Brzozowski również podkreśla wymiar wychowawczo-dydaktyczny: Żywot Józefa to utwór, którego myślą przewodnią jest zwycięstwo cnoty i zwalczanie pokusy, zachęcający rodaków do dobrego postępowania; Wizerunk mówi o młodzieńcu, który dzięki radom odkrywa, że najważniejsza jest cnota i wartość moralna człowieka; przypowieści i powiastki Zwierzyńca ukazują, co naśladować, a czego się wystrzegać; w Krótkiej rozprawie bohaterowie wytykają sobie wzajemnie wady, aby zachęcić do ich przezwyciężania. Jedynie Figliki ujęto poza tymi kategoriami jako dykteryjki ze szczerym humorem typowym dla charakteru Reja. Dopełnia tę charakterystykę mały wybór Rejowych epigramatów i wyjętych z jego twórczości sentencji, które mają dać pojęcie o sposobie pisania, humorze i prawdzie zawartej dziełach (Co dziesięć koni pasał, Miła rzecz swoboda, Mądry Polak po szkodzie, Piesek a osieł, Zdania i przypowieści, Fraszki i dowcipy).

Tę biografię Reja-samouka i opis jego twórczości dydaktycznej dopełnia u Brzozowskiego jeszcze jeden aspekt ważny dla pisarza oświatowego początku XX w.: Rej „Zachęca do umiejętności czytania i pisania” (s. 10). Cytat z Żywota człowieka poczciwego mówi o czerpaniu rozkoszy i pożytku z lektury, pozna-

17 J. Ławski, Żywot protestanta poczciwego. Mikołaj Rej w lekturze Adama Mickiewicza, w: Mikołaj Rej-w pięćsetlecie urodzin. 
waniu dzięki niej świata ludzi i natury oraz mądrości wieków. Tę zachętę sprzed 400 lat Brzozowski z pewnością przeadresowuje do odbiorców swej książeczki o Reju - ludu i młodzieży. Pisarz staropolski - którego biografia ukazuje przejście od nieuctwa do wiedzy, od beztroskiej amoralności do wychowywania przez literaturę dydaktyczną, od bezsensownego trwonienia czasu do budującej lektury - okazuje się w tej zachęcie ważnym sprzymierzeńcem, potwierdzającym ją autorytatywnie własnym doświadczeniem.

\section{Mikołaj Rej z Nagłowic w „Towarzyszu Młodzieży”}

W jubileuszowym $1905 \mathrm{r}$. w dwóch numerach periodyku „Towarzysz Młodzieży” (nr 9-10), dodatku do warszawskiego czasopisma kulturalno-społecznego „Tygodnik Ilustrowany”, autor ukrywający się pod kryptonimem H. L. ogłosił rozprawkę Mikołaj Rej z Nagłowic. Przyciągała ona umieszczoną na pierwszej stronie ryciną, zaczerpniętą z pierwodruku Apocalypsis (Kraków 1565), przedstawiającą 50-letniego Reja i podpisaną jak w starodruku epigramatem o pisarzu jako polskim Ulissesie, który zdobył wieczną sławę. Adres czytelniczy rozprawki jest nieco inny niż broszury Brzozowskiego, związany naturalnie ze środowiskiem czytelników „Tygodnika Ilustrowanego”, ale i oczywiście z wiekiem odbiorców dodatku do pisma. To tekst dla młodzieży, a nie dla młodzieży i ludu, ale, rzecz jasna, jego cel jest edukacyjno-wychowawczy. Mimo związanej z tym innym adresem odmienności - mniej uproszczonego języka i sposobu formułowania myśli - uderza podobieństwo rozłożenia akcentów w biografii pisarza. Podobieństwa tego nie uzasadnia tylko wspólne źródło tekstów w biografii Reja pióra Trzecieskiego, ponieważ obydwaj autorzy dokonywali z tej biografii wyboru, a autor „Towarzysza Młodzieży” odważniej ją komentował.

H. L., podobnie jak Brzozowski, interesuje się przede wszystkim Rejową edukacją. Już w pierwszym zdaniu, obok informacji o czasie i miejscu urodzenia, znajdujemy znaczący komentarz do XVI-wiecznej relacji o dzieciństwie pisarza: „w pacholęcych latach był zaniedbany zupełnie pod względem wychowania i nauki" (s. 98) ${ }^{18}$. Informacje o kolejnych szkołach - skrzętnie wymienionych

18 H. L., Mikołaj Rej z Nagłowic, „Towarzysz Młodziėzy”, 1905, nr 9, s. 98-100; nr 10, s. 110-111. Cytaty z publikacji lokalizujemy, podając numery stron w nawiasach po przytoczeniach. 
placówkach w Skalbmierzu, Lwowie i Krakowie - opatrzono komentarzem o nauce „bez powodzenia i chęci” (s. 98). Relacja o pobycie na dworze Tęczyńskiego zawiera (jak u Brzozowskiego) dopowiedzenie o pozytywnym wpływie tego okresu na Reja, który zaczął wykorzystywać wrodzony talent i rozwinął się intelektualnie w kontakcie z wykształconymi ludźmi. W.L. stara się też doprecyzować przekaz Trzecieskiego o zdobyciu podstaw łaciny i własnych lekturach Reja, które pozwoliły samoukowi stać się pisarzem - identyfikuje te lektury jako popularne wówczas wśród szlachty wyciągi z dzieł filozofów i moralistów oraz Biblię. Charakteryzując za Trzecieskim Reja jako żywego, wesołego i przyjacielskiego, autor wskazuje także na jego osobiste związki z wielkimi tego świata (wojewodą Mikołajem Sieniawskim, Zygmuntem Starym i Zygmuntem Augustem, królową Boną, uczonymi, magnatami) oraz jego ustatkowanie rodzinno-majątkowe (ożenek, założenie Rejowca, udział w obradach sejmu). Tym samym ukazuje młodym czytelnikom awans społeczny czy publiczny pisarza, związany z nauką i rozwojem intelektualnym. Z tym obrazem Reja w gronie największych ludzi jego epoki współgra zamieszczona na końcu rozprawki rozbudowana informacja o Rzeczypospolitej Babińskiej, uwiecznionym na obrazie Jana Matejki z 1881 r. zmityzowanym stowarzyszeniu literackim, do którego Rej miał należeć wraz z Janem Kochanowskim czy Janem Zamoyskim, a nawet królem Zygmuntem Augustem.

W.L., w przeciwieństwie do Brzozowskiego, nie pomija kwestii związków innowierczych Reja. Słusznie stwierdza, że pisarz protestanckimi „zasadami się przejął i w pismach swoich dzielnie je popierał" (s. 98). Następnie jednak, w sposób typowy dla XIX-wiecznej narracji o Reju, bez uzasadnienia nadinterpretowuje jego ostateczny związek z katolicyzmem - podobnie jak na przykład Kazimierz Józef Turowski, wydawca jednej z najpopularniejszych w XIX w. edycji Żywota człowieka poćciwego w serii „Biblioteka Polska” (Kraków 1859) ${ }^{19}$. W.L. pisze o ufundowaniu przez Reja miasta Oksza „z murowanym kościołem katolickim" (s. 98), podczas gdy Trzecieski nie określił przynależności konfesyjnej tej świątyni, a fakty historyczne mówią o jej przejęciu przez katolików od kalwinistów w 1678 r. Autor nie podaje żadnych szczegółów drogi konfesyjnej Reja, nie wiemy, czy według niego pisarz dokonał najpierw konwersji

19 M. Rej, Żywot człowieka poczciwego, wyd. K. J. Turowski, Kraków 1859, s. 23. 
na protestantyzm, a potem na katolicyzm, czy może jego poparcie dla protestantyzmu nie miało nigdy charakteru formalnego i zniknęło z wiekiem. Jednak informacja o fundacji katolickiego kościoła u kresu życia neutralizuje tu problem pisarzy oświatowych z Rejem-protestantem, o którym wspominaliśmy na wstępie. Ostatecznie podsumowanie biografii w „Towarzyszu Młodzieży" bardzo pozytywnie waloryzuje dokonaną na drodze nieregularnej edukacji przemianę Reja z młodzieńca-nieuka w statecznego szlachcica-katolika: „Po burzliwej bardzo młodości spoważniał na starość i lubował się w rozmyślaniach poważnych. [...] Jako młodzieniec zaczął Rej ogłaszać drobne utwory, w statecznym wieku wydawał dzieła poważniejsze" (s. 98).

Do tego skrótowego omówienia życia i charakteru pisarza nieco nie przystaje szczegółowe, niemal profesjonalne wyliczenie jego większych i mniejszych dzieł, zawierające szczegóły bibliograficzne i opis pierwodruków, a czytelnikom „Towarzysza Młodzieży” dostarczające systematycznej wiedzy, której nie mogli otrzymać w szkole. Ważniejsze utwory zostały tu omówione w oparciu o opracowania historycznoliterackie (np. anachronizmy chrześcijańskie w Żywocie Józefa, Postylla jako jeden z pomników polskiej sztuki typograficznej, Zwierzyniec jako zawierający pierwsze polskie bajki zwierzęce). Niespójnie wobec wcześniej przedstawionej wizji katolickiego ustatkowania i poważnej twórczości w starszym wieku zwrócono uwagę na „Nieprzystojne żarty z duchowieństwa, szydercze anegdoty o Litwinach, zbyt rubaszne powiastki" w Figlikach. Wśród dzieł doceniono szczególnie Źwierciadło, przy którego lekturze „myśl przenosi się do siedzib przodków naszych, w epoce Reja. Widzimy, jaki podówczas był rząd, gospodarstwo, handel, widzimy najdrobniejsze szczegóły domowych zabaw, strojów, pojazdów, wzajemnych odwiedzin, słowem: widzimy obraz domowego życia Polaków" (s. 110). Tę charakterystykę dopełniają cytaty z Postylli z przypisami objaśniającymi archaizmy i z informacją o zmodernizowaniu pisowni, aby tekst był zrozumiały dla czytelników periodyku, a także przytoczenie dwóch „bajek” epigramatów Chłop i wąż i Osieł co chciał kuglować.

Jednak podsumowanie całej rozprawki - biografii oraz charakterystyki postaci i twórczości Reja - stanowi znów kwestia emancypacji języka polskiego w literaturze i kulturze. Oto Rej jako pierwszy uczynił polszczyznę językiem literackim. Jego żywy, bogaty i wesoły język ma „barwę czysto rodzimą” (s. 110), bo nie kształcił się na obcych wzorach. Autor „Towarzysza Młodzieży” nie powiedział tego wprost, ale z jego słów jasno wynika: to szczytne i godne 
naśladowania dla młodych, że Rej opamiętał się po latach dziecięcej beztroski, zdobywając wiedzę i elementy wykształcenia, ale to właśnie jego początkowe nieuctwo i późniejsze nieregularne samouctwo ukształtowały jego cudowną polszczyznę, która dla polskiej kultury aż po XX w. pozostaje główną wartością jego życia i dzieła.

\section{Przygody Imć Pana Mikołaja Reja Zuzanny Morawskiej}

W 1905 r. w „Wieczorach Rodzinnych. Tygodniku Ilustrowanym dla Młodzieży i Dzieci" (nr 1-44) ogłoszono w odcinkach Przygody Imć Pana Mikołaja. Powieść $z$ XVI w. (Warszawa 1905-1906) pióra autorki powiastek dla dzieci i młodzieży, działaczki oświatowej Zuzanny Morawskiej (1840-1922) ${ }^{20}$. W 1906 r. tekst wyszedł w Warszawie u Gebethnera i Wolfa jako Przygody Imć Pana Mikołaja Reja. Powieść z XVI wieku dla młodzieży z 6-ciu rysunkami K[onstantego] Gorskiego. To utwór zaliczany do historycznych powieści typu pozytywistycznego ${ }^{21}$.

W „Wieczorach Rodzinnych” - czasopiśmie wydawanym nakładem Marii z Chomętowskich Balińskiej przez zespół, do którego należeli Ludwika Hauke i autorzy pism dla młodzieży tacy jak Maria Julia Zaleska czy Władysław Umiński - redakcja opatrzyła pierwszy odcinek powieści przypisem o okolicznościowym charakterze publikacji. Zaznaczono, że powodem czczenia dawnego pisarza i opowiadania jego biografii jest fakt, że „położył dla języka i piśmiennictwa naszego wielkie zasługi, bo był pierwszym wybitniejszym autorem, który pisał tylko po polsku i wpływał na to, aby język ojczysty wyparł łacinę z literatury” (s. 4) ${ }^{22}$. Cel publikacji stanowi „upamiętnienie” „w umysłach [...] czytelni-

20 G. Skotnicka, Z zagadnień historycznej beletrystyki dla dzieci i młodzieży Zuzanny Morawskiej, w: O literaturze dla dzieci i młodzieży. Studia, rozprawy, szkice, red. H. Skrobiszewska, Warszawa 1975; J. Z. Białek, G. Skotnicka, Morawska Zuzanna, w: Polski słownik biograficzny, t. 21, Wrocław 1976; G. Leszczyński, Morawska Zuzanna, w: Stownik literatury dziecięcej i młodzieżowej, red. B. Tylicka, G. Leszczyński, Wrocław 2002; Zuzanna Morawska - pisarka i pedagog, „Ciechanowskie Zeszyty Literackie", 17 (2015).

21 G. Skotnicka, Pozytywistyczne powieści, s. 189-192.

22 Z. Morawska, Przygody Imć Pana Mikołaja. Powieść $z$ XVI w., „Wieczory Rodzinne”, 1905, nr 1-44. Cytaty z publikacji lokalizujemy, podając numery stron w nawiasach po przytoczeniach. 
ków" obchodzonej rocznicy - Rej to pisarz na tyle ważny, by młody czytelnik dzięki dziełu literackiemu jak najlepiej zapamiętał jego jubileusz. Utwór określono jako „życiorys Reja, skreślony na tle życia ówczesnego, w formie barwnego i zajmującego opowiadania przez zasłużoną autorkę wielu powieści historycznych" (s. 5). Spodziewamy się więc ujęcia biograficznego na tle epoki - i takie otrzymujemy. Powieść przedstawia chronologicznie (z niewielkimi retrospekcjami w narracji, np. o pierwszym małżeństwie ojca Reja) historię życia pisarza, od dzieciństwa dziesięciolatka do 1569 r., gdy 2 czy 3 miesiące przed śmiercią Rej uczestniczy w Lublinie w świętowaniu unii polsko-litewskiej; lwia część tej opowieści dla dzieci i młodzieży (XXVI z XXVIII rozdziałów) przedstawia dzieciństwo i młodość bohatera. Kolejne rozdziały mają charakter anegdot czy dykteryjek, których źródło lub inspirację stanowią XVI-wieczne przekazy, przede wszystkim Trzecieskiego, ale także fantazja powieściopisarki, starającej się kształtować postać bohatera i wydarzenia w fabule tak, by współgrały z przekazami historycznymi o cechach pisarza i wydarzeniach z jego życia. Morawska mierzy się z obydwoma elementami biografii Reja, które wskazaliśmy na wstępie jako problematyczne dydaktycznie - zagadnieniami braku wykształcenia i sympatii proreformacyjnych, znamiennie łącząc je ze sobą nawzajem oraz z kwestią roli Reja w kulturalnej emancypacji polszczyzny.

Stałymi elementami charakterystyki Reja są tu zarówno nonszalancki stosunek do wykształcenia, jak i nieuznawanie praw i godności duchowieństwa ${ }^{23}$. Antyklerykalne ukierunkowanie psotnego temperamentu „Mikołajka” poznajemy, gdy na kartach powieści po raz pierwszy pojawia się ksiądz - stryj bohatera, a ten neguje oczywistą dla innych konieczność usługiwania mu i drwi z jego kar czy pouczeń. Stale atakuje duchownych m.in. za praktykę postów, choć nie bez znaczenia pozostaje fakt, że on sam jest ukazany jako z natury i wychowania nieumiarkowany (to oczywiście obraz z XVI-wiecznego paszkwilu Wereszczyńskiego, choć Morawska nie przejmuje z niego negatywnego stosunku do pisarza). Jednak dwa najczęstsze zarzuty powieściowego Reja pod adresem kleru - chciwość dóbr materialnych i władzy oraz zaniedbywanie nauczania

23 M. M. Kacprzak, Smok z Okszy jako bohater budującej powieści dla młodzieży w „Przygodach imć pana Mikołaja Reja" Zuzanny Morawskiej (1906). Z dziejów XIX-wiecznej recepcji twórczości religijnej Reja, w: Libris satiari nequeo. Oto ksiag jestem niesyty. Pamięci Ewy J. Głębickiej, red. J. Partyka, A. Masłowska-Nowak, Warszawa 2010. 
po polsku - nie wypływają z wad bohatera, ale z jego oburzenia na krzywdę wiernych i instrumentalne traktowanie religii. To zgorszenie prowadzi Reja do protestantyzmu. Autorka, która ten zwrot konfesyjny ocenia krytycznie, tłumaczy go jednak dobrymi intencjami, a także nieświadomością i niedostatkiem edukacji. Narrator arbitralnie stwierdza niewłaściwość sądu Mikołaja o ówczesnym stanie Kościoła, jako źródło błędu wskazując pochopne uogólnienie obserwacji szczegółowej: „Umysł jego niewykształcony nie zdawał sobie sprawy, że ówcześni duchowni, z małym wyjątkiem, nie tylko pracowali nad utrzymaniem wiary świętej, ale krzewili nauki i stali na straży dobra Rzeczypospolitej" (s. 281) ${ }^{24}$. Od początku opowieści obserwujemy przyczyny i przejawy owego niewykształcenia umysłu - niefrasobliwość dziesięcioletniego analfabety czy niesystematyczność podjętej nauki, traktowanej jako zabawa przez zdolnego i dość chętnego, ale nieposkromionego ucznia. Stąd płynące niewyrobienie umysłowe i duchowe, niedostatek wiedzy i niedojrzałość intelektualna, trafiając na zły przykład, prowadzą młodego Mikołaja ku poglądom protestanckim. Do zasłyszanych informacji o reformie Lutra podchodzi on po amatorsku i naiwnie, ale i z głęboką ciekawością poznawczą, co widać choćby w jego refleksji o miejscu języka narodowego w życiu religijnym. Jak bowiem wspomniano, w antyklerykalizmie Reja ważne miejsce zajmuje zarzut zaniedbania nauczania wiary w języku ojczystym. Bohater gardzi łaciną. Mimo fenomenalnej pamięci, która pozwala mu powtarzać bez zrozumienia teksty w tym języku, powieściowy Mikołaj stawia opór jego nauce, pyta o sens używania innego języka niż ojczysty, stwierdza głupotę uczonych posługujących się łaciną i bezsens mówienia językiem umarłych. Stopniowo rozwija teorię języka naturalnego, opartą na idei wykorzystania darów Stwórcy. Wreszcie z miłości do ojczyzny świadomie podejmuje decyzję o posługiwaniu się polszczyzną w literaturze, wygłasza przed królem słynne słowa o nie-gęsim języku Polaków i wychwala Zygmunta Augusta za promowanie języka narodowego. Rola Reja w emancypacji polszczyzny wyrasta więc z jego niechęci do nauki i łączy się z jego błędnymi rozpoznaniami konfesyjnymi, ale kształtuje się w motywacji patriotycznej i religijnej.

24 Z. Morawska, Przygody Imć Pana Mikołaja Reja. Powieść z XVI wieku dla młodzieży z 6-ciu rysunkami K. Gorskiego, Warszawa 1906. Powieść cytujemy za wydaniem książkowym, lokalizując cytaty przez podanie numerów stron w nawiasach po przytoczeniach. 
Znamienne, że Morawska ukazuje Reja równocześnie jako zwolennika reformacji i wiernego katolika. Mówi o jego pracy nad protestanckim katechizmem, ale nie wspomina o licznych innych tekstach religijnych, których spis za Trzecieskim powtarzano niejednokrotnie w XIX w., choćby w Herbarzu polskim Kaspra Niesieckiego ${ }^{25}$. Pominięcie tego tematu pozwala nie przeciążać fabuły i narracji dla młodego odbiorcy informacjami historycznoliterackimi, ale z pewnością wynika także z niechęci do ukazywania bohatera jako związanego z propagowaniem protestantyzmu. Powieściopisarka podkreśla fascynację religią, ale i ignorancję teologiczną Reja. Nie rozumiejąc różnic dogmatycznych, łatwo przyznaje on rację poglądom, które go pociągają, ale i łatwo je zmienia pod wpływem perswazji. Wielokrotnie podkreślane jego zasadniczo pozytywne cechy: otwartość na idee, ciekawość poznawcza, uczenie się przez słuchanie - w sferze refleksji religijnej wiodą go na manowce. Zresztą bohater ostatecznie ma świadomość tych ograniczeń i wyraża żal z powodu braków książkowej edukacji i niedostatecznego rozeznania w kwestiach doktrynalnych. I tak jego nieuctwo - zasadniczo krytykowane - wykorzystuje autorka powieści do jego obrony, do usprawiedliwienia jego fascynacji protestantyzmem. Równocześnie, eksponując tę ignorancję, przypisuje mu rodzaj nieintelektualnego, intuicyjnego wyczucia religijnego, które wyraża się w przekonaniu o pierwszeństwie relacji człowieka z Bogiem i modlitwy przed kwestiami doktrynalnymi.

Rej u Morawskiej, nie umiejąc, ale i nie chcąc podjąć decyzji o charakterze konfesyjnym, pozostaje przy katolicyzmie do końca życia i wychowuje w nim dzieci. W odpowiedzi na zarzuty odstępstwa, choć krytykuje duchownych, deklaruje przynależność do Kościoła rzymskiego, a narrator mówi o już dojrzałym pisarzu, że „nie zmienił [...] wyznania i jako za lat młodych, tak i teraz nie wiedział, jakiego stale się trzymać" (s. 338). Jednak mimo, że z uwagi na dydaktyczną wymowę powieści to niewygodne, Rej Morawskiej pozostaje człowiekiem zaangażowanym w spory religijne epoki. Pisarka nie kryje jego antykatolickich, a zwłaszcza antyklerykalnych poglądów i dość trafnie relacjonuje jego najważniejsze zarzuty wobec Kościoła rzymskiego. Zarazem broni przed nim Kościoła, podkreślając błędność sądów niewykształconego pisarza. Ale to także obrona Reja - wprawdzie źle wychowanego i wpływowego, zbyt późno

25 Rey, w: K. Niesiecki, Herbarz polski, wyd. J. N. Bobrowicz, Lipsk 1841, S. 109-110. 
rozpoznającego swe nieuctwo, ale pełnego dobrych chęci i błądzącego nieświadomie. Podobnie jak na przykład Klementyna Hoffmanowa, Morawska upatruje przyczyny związku Reja z protestantyzmem w braku regularnej edukacji, niedouczeniu, niewyrobieniu duchowym, podleganiu przez to złym wpływom i klimatowi epoki ${ }^{26}$. W strategii usprawiedliwiania go, twierdząc, że nigdy nie podjął decyzji konfesyjnej wbrew katolicyzmowi, wykorzystuje nawet jego wady - oprócz podkreślanego przez Trzecieskiego niewykształcenia także cechy z paszkwilu Wereszczyńskiego: chwiejność poglądów i folgowanie słabościom. Cała ta komplikacja w charakterystyce bohatera i strukturze fabuły i narracji warta jest jednak zachodu pisarki-pedagoga na progu XX w. - biografia Reja jest bowiem biografią bojownika o język polski i ojca polskiej literatury.

\section{Determinacja pisarzy oświatowych}

Analiza trzech przykładów pism związanych z 40o-leciem urodzin Mikołaja Reja (książeczki popularyzatorskiej dla ludu i młodzieży, rozprawki w periodyku dla młodzieży i powieści historycznej dla młodego odbiorcy) pokazuje, że determinacja autorów, aby wykorzystać w celach budujących postać staropolskiego pisarza w latach związanych z jego jubileuszem (ok. 1900-1910), była tak duża, że starano się niemal za wszelką cenę przezwyciężać trudności ideowe i pedagogiczne w ukazywaniu Reja jako wzoru, a jego twórczości jako nośnika pozytywnych wartości. Podstawowymi trudnościami był utrwalony obraz Reja jako nieuka oraz jego zaangażowanie religijne po stronie protestantyzmu, skutkujące przekazami o jego amoralności. Problem drugi był rozwiązywany na trzy sposoby: pomijano kwestie religijne w życiu i twórczości Reja, informowano o jego trwałym lub przywróconym katolicyzmie (wbrew brakowi dowodów historycznych i silnych przesłankach do uznania go za związanego z ewangelicyzmem do śmierci) albo tłumaczono problem drugi problemem pierwszym, czyli skłonność do protestantyzmu - brakiem wykształcenia. Natomiast problem negatywnego stosunku pisarza do regularnego wykształcenia rozwiązywano, ukazując swoiste „nawrócenie” dojrzałego Reja także w tej dziedzinie, jego drogę do uznania wartości nauki i wiedzy. Zarazem ukazywano pozytywne skutki

26 K. Hoffmanowa, Wyjątki służące do ukształcenia serca i stylu, w: tejże, Dzieła, red. N. Żmichowska, Warszawa 1876, t. 3, s. 16. 
braku regularnego wykształcenia opartego na obcych wzorach, podkreślając rodzimość Rejowej polszczyzny. Bowiem dla pisarzy oświatowych przełomu XIX/ xX i początku XX w. niepodważalną wartością biografii i pism Reja, godną owej determinacji radzenia sobie $\mathrm{z}$ faktami i opiniami niewygodnymi dydaktycznie, pozostawała jego troska o rolę języka polskiego w literaturze, religii, oświacie i wychowaniu, pozwalająca czynić go patronem walki o język polski w szkole i kulturze oraz promocji nauki czytania i czytelnictwa. Jak napisał redaktor warszawskiej „Biesiady Literackiej”, łącząc w komentarzu prasowym niepokój o losy wydawnicze periodyku „Poradnik Językowy” i tzw. warszawskiego Słownika języka polskiego z zaleceniem świętowania jubileuszu dawnego pisarza, który był wprawdzie niedoskonałym i pochopnym człowiekiem, ale walczył o wartości ponadczasowo ważne dla narodu polskiego, zarówno w Rzeczypospolitej XVI w., jak i w Królestwie Polskim na progu XX w.: „Dzieją się te krzywdy oświacie narodowej w chwili obchodu rocznicy wyzwolenia języka polskiego przez Mikołaja Reja z cudzoziemszczyzny, kiedy wszyscy pragniemy okazać wdzięczność rymotwórcy za to, że się odważnie zapytał: czy możemy być narodem bez języka macierzystego? [...] Z wielkiej dla naszego narodu rocznicy usuńmy wszystko, co dla nas jest w działalności Reja niepożądanego, a idźmy za głosem miłości matczynej, która jednocześnie umie karcić i przebaczaćm ${ }^{27}$.

Streszczenie: Rocznica urodzin Mikołaja Reja w 1905 r. to jeden z jubileuszy XIX i początku XX w., podczas których w przypominano w duchu patriotycznym dzieje dawnej Rzeczypospolitej oraz przedstawiano dawnych pisarzy polskich jako wzorce osobowe, a ich twórczość jako wychowawczą. Opublikowano wówczas liczne prace historycznoliterackie, edytorskie i popularyzatorskie, a także oświatowo-wychowawcze. Biografię staropolskiego pisarza wykorzystywano w nich w celach pedagogicznych. Artykuł analizuje trzy przykłady publikacji dla dzieci i młodzieży oraz ludu. Ukazuje, w jaki sposób ich autorzy przezwyciężali trudności ideowe i pedagogiczne (związane ze stereotypem Reja-nieuka oraz z zaangażowaniem pisarza w spory religijne XVI w.), aby przedstawiać go jako wzór do naśladowania i patrona współczesnej pracy oświatowej.

Słowa kluczowe: biografia pisarza, historia oświaty i wychowania, literatura dla dzieci i młodzieży, recepcja kultury staropolskiej, Mikołaj Rej.

27 Sęp [Władysław Józef Maleszewski], Z Warszawy - Rocznica rejowska, „Biesiada Literacka", 59 (1905) nr 7-8, s. 106. 


\section{Bibliografia}

Białek J. Z., Skotnicka G., Morawska Zuzanna, w: Polski słownik biograficzny, t. 21, Wrocław 1976, s. 702-703.

Bruchnalski W., Mikołaj Rej 1505-1905. Odczyt wygłoszony w sali Teatru Lwowskiego podczas Uroczystości jubileuszowej 17 grudnia 1905, Lwów 1906.

Brzozowski B., Mikołaj Rej z Nagłowic, Warszawa 1900.

Chlebowski B., Mikołaj Rej jako pisarz. Odbitka z książki zbiorowej pt. „Z wieku Reja” ku uczczeniu czterechsetnej rocznicy urodzin poety, Warszawa 1905.

Chrobot A., Mikołaj Rej w twórczości Andrzeja Trzecieskiego, w: Mikołaj Rej z Nagłowic. W pięćsetna rocznicę urodzin, red. W. Kowalski, Kielce 2005, s. 105-112.

Górski R., Literatura dla ludu, w: Słownik literatury polskiej XIX wieku, red. J. Bachórz, A. Kowalczykowa, Wrocław 1991, s. 496-497.

H. L., Mikołaj Rej z Nagłowic, „Towarzysz Młodzieży”, 1905, nr 9, s. 98-100; nr 10, S. 110-111.

Hahn W., Bibliografia o Mikołaju Reju za rok 1905, „Pamiętnik Literacki”, 4 (1905) S. 569-578.

Hoffmanowa K., Wyjątki służace do ukształcenia serca i stylu, w: tejże, Dzieła, red. N. Żmichowska, Warszawa 1876, t. 3, s. 16.

Jan Kochanowski z Czarnolasu. Opowiadanie, Warszawa 1883.

Juszyński M. H., Dykcjonarz poetów polskich, t. 2, Kraków 1820.

Kacprzak M. M., Edycje literatury staropolskiej w życiu Polaków XIX w. na przykładzie wydań „Zwierciadła” Mikołaja Reja, w: Na co dzień i od święta. Książka w życiu Polaków w XIX-XXI wieku, red. A. Chamera-Nowak, D. Jarosz, Warszawa 2015, s. 71-90.

Kacprzak M. M., Jan z Czarnolasu jako bohater literacki w poezji polskiej XIX w. Z dziejów recepcji spuścizny Kochanowskiego i kultury staropolskiej w wieku XIX, w: Wiazanie sobótkowe. Studia o Kochanowskim, red. E. Lasocińska, W. Pawlak, Warszawa 2015, s. 448-470.

Kacprzak M. M., Smok z Okszy jako bohater budującej powieści dla młodzieży w „Przygodach imć pana Mikołaja Reja" Zuzanny Morawskiej (1906). Z dziejów XIX-wiecznej recepcji twórczości religijnej Reja, w: Libris satiari nequeo. Oto ksiąg jestem niesyty. Pamięci Ewy J. Głębickiej, red. J. Partyka, A. Masłowska-Nowak, Warszawa 2010, s. 211-224.

Kacprzak M. M., XIX-wieczne edycje dzieł Adama Mickiewicza dla dzieci i młodzieży, w: Aspekty działalności wydawniczej w XIX i początkach XX wieku, red. I. Michalska, G. Michalski, Łódź 2016, s. 73-100.

Kallenbach J., Mikołaj Rey. Szkic jubileuszowy, Kraków 1906.

Kowalczuk U., 1884 - jubileuszowa „renowacja” Kochanowskiego, w: Upominki od narodu. Jubileusze, rocznice, obchody pisarzy, red. T. Budrewicz i in., Żarnowiec 2000, s. 103-119. 
Kuran M., Mikołaj Rej w opinii polskiej kontrreformacji (na przykładzie „Postylli katolicznej" Jakuba Wujka), w: Mikołaj Rej - w pięćsetlecie urodzin, red. J. Okoń i in., cz. 2: Interpretacje, recepcja, Łódź 2005, s. 109-122.

Leszczyński G., Morawska Zuzanna, w: Słownik literatury dziecięcej i młodzieżowej, red. B. Tylicka, G. Leszczyński, Wrocław 2002, s. 252.

Ławski J., Żywot protestanta poczciwego. Mikołaj Rej w lekturze Adama Mickiewicza, w: Mikołaj Rej - w pięćsetlecie urodzin, red. J. Okoń i in., cz. 2: Interpretacje, recepcja, Łódź 2005, s. 211-248.

Maciuszko J. T., Mikołaj Rej. Zapomniany teolog ewangelicki XVI w., Warszawa 2002.

Magiera J., Mikołaj Rej. Ojciec piśmiennictwa polskiego. Opowiadanie z dziejów literatury polskiej. W czterechsetletna rocznicę urodzin Reja 1505-1905, Kraków 1905.

Maleszewski W. J., Z Warszawy - Rocznica rejowska, „Biesiada Literacka”, 59 (1905) nr 7-8, s. 106.

Mazurkowa B., Glosa do recepcji „Zwierciadła” Mikołaja Reja (XVI-XVIII w.), w: Mikołaj Rej - w pięćsetlecie urodzin, red. J. Okoń i in., cz. 2: Interpretacje, recepcja, Łódź 2005, s. $187-210$.

Morawska Z., Przygody Imć Pana Mikołaja Reja. Powieść z XVI wieku dla młodzieży z 6-ciu rysunkami K. Gorskiego, Warszawa 1906.

Morawska Z., Przygody Imć Pana Mikołaja. Powieść z XVI w., „Wieczory Rodzinne”, 1905, nr 1-44.

Niesiecki K., Herbarz polski, wyd. J. N. Bobrowicz, Lipsk 1841.

Niewolak-Krzywda A., W kręgu rzeczy czarnoleskiej, Rzeszów 1987.

Nieznanowski S., Recepcja Reja w literaturze staropolskiej, w: Mikołaj Rej. W czterechsetlecie śmierci, red. T. Bieńkowski, J. Pelc, K. Pisarkowa, Wrocław 1971, s. 221-243.

Nowaczyński A., Wizerunek Mikołaja Reja z Nagłowicz, Warszawa 1905.

Ostrowska E., Z dziejów języka polskiego i jego piękna. Studia i szkice, Kraków 1978.

Pieniążek C., O życiu i dziełach Mikołaja Reja z Nagłowic, Lwów 1905.

Prószyński K., O Janie Kochanowskim z Czarnolasu, jego pieśniach i pamiątkach po nim, w 300 lat po śmierci tego pieśniarza, Warszawa 1884.

Rej M., Żywot człowieka poczciwego, Warszawa 1828.

Rej M., Żywot człowieka poczciwego, wyd. K. J. Turowski, Kraków 1859.

Sandoz M., Obrazki z życia Jana Kochanowskiego, Kraków 1884.

Sempołowska S., Zasady moralne a literatura dla dzieci, „Poradnik dla Czytających Książki", 23 (1901) s. 8-10.

Skotnicka G., Pozytywistyczne powieści z dziejów narodu dla dzieci i młodzieży, Gdańsk 1974.

Skotnicka G., Z zagadnień historycznej beletrystyki dla dzieci i młodzieży Zuzanny Morawskiej (Tematyka, bohater, narracja), w: O literaturze dla dzieci i młodzieży. Studia, rozprawy, szkice, red. H. Skrobiszewska, Warszawa 1975, s. 126-155. 
Sokalski B., O Janie Kochanowskim, jego życiu i dziełach, Złoczów 1884.

Ścisłowska Z., Jan Kochanowski, dziedzic Czarnolasu, obrazek historyczny z XVI wieku, popularne opowiadanie, Kraków 1884.

Tatomir L., Jan Kochanowski, Lwów 1884.

Walecki W., Święty Rej. Dwa przypomnienia: o człowieku i o pisarzu, w: Mikołaj Rej $z$ Nagłowic. Sylwetka - twórczość - epoka, red. M. Garbaczowa, Kielce 1997, s. 59-65.

Witczak T., Spór o „Żywot i sprawy poćciwego szlachcica polskiego Mikołaja Reja $z$ Nagłowic”, „Pamiętnik Literacki”, 65 (1974) nr 2, s. 3-44.

Wójcicki K. W., Z rodzinnej zagrody. Życiorysy, Warszawa 1877.

Złote myśli Mikołaja Reja, wybrał i ułożył R. Kwiatkowski, Warszawa 1906.

Zuzanna Morawska - pisarka i pedagog, „Ciechanowskie Zeszyty Literackie”, 17 (2015). 